BÖLCSKEI-FARKAS-SLíz szerk., Magyar és nemzetközi névtani terminológia. Hungarian and International Onomastic Terminology. International Council of Onomastic Sciences - Magyar Nyelvtudományi Társaság, Uppsala-Budapest, 2017. 49-61. DOI: $10.26546 / 5061110.8$

\title{
Két nemzetközi névtani terminológiai jegyzék magyar változata
}

1. Két nemzetközi névtani terminológiai szójegyzék. A jelen kötetben közreadott két nemzetközi névtani terminológiai szójegyzéket tulajdonnevekkel foglalkozó nemzetközi tudományos, szakmai társaságok terminológiai munkálatokra szakosodott munkacsoportjai alkották meg, eltérő céllal. Az ICOS (International Council of Onomastic Sciences), azaz a Nemzetközi Névtudományi Társaság szakemberei általánosságban a névtan tudományterületének alapvető, elsősorban a szűkebb szakmai kommunikáció során alkalmazott szakkifejezéseit gyüjtötték össze, látták el értelmező magyarázatokkal, s tették közzé a névtani terminológiára vonatkozó megjegyzések, szakirodalmi hivatkozások kíséretében. Az UNGEGN (United Nations Group of Experts on Geographical Names), azaz az ENSZ Földrajzi Névi Szakértői Csoportja munkatársai a földrajzinévegységesítési tevékenység során használatos nyelvészeti, földrajzi, térképészeti, dokumentációs és információtechnológiai vonatkozású terminusok jegyzékét készítették el, a helynevek standardizálásának gyakorlati munkájában részt vevő szakemberek számára. Az alábbiakban e két, különböző jellegű nemzetközi névtani terminológiai glosszárium keletkezési körülményeiröl, jellemzőiről, valamint a magyar változatok elkészítésének elveiröl és módjáról nyújtunk rövid tájékoztatást.

2. Az ICOS fóbb törekvései. Az 1949-ben alapított Nemzetközi Névtudományi Társaság 2002-ben megszövegezett, jelenleg érvényes alapszabályzatában céljai között a névtudomány nemzetközi színtéren és interdiszciplináris keretek között való előmozdítását, koordinálását, valamint rendszeres tudományos-szakmai találkozók rendezését jelöli meg. A szervezet korábbi és jelenlegi sikeres müködéséhez nagyban hozzájárul két állandó munkacsoport, a bibliográfiai (ICOS Bibliography Group) és terminológiai munkacsoport (ICOS Terminology Group) tevékenysége is (Icosweb, FARKAS 2015: 23-24, 26-27, 28, 31).

Az ICOS Terminológiai Munkacsoportjának létrehozását a 2002-es uppsalai ICOSkongresszuson a cseh Milan Harvalík, az ICOS jelenlegi elnöke kezdeményezte. A munkacsoport 2004-ben kezdte meg müködését, s az Icosweb honlapjának Terminology aloldalán 2011-ben két kisebb terjedelmü terminusjegyzéket tett közzé (vö. HARVALÍK 2005, 2014). Az egyik jegyzék néhány angol nyelvü, föként a szük szakmai közösség által használatos névtani szakkifejezést tartalmaz, a jelentés rövid meghatározásával, valamint közöl néhány, a névtani terminusok nyelvi jellemzőivel kapcsolatos általános megjegyzést is (Icosweb Terminology). A másik terminusgyüjtemény 70 alapvető 
névtani szakkifejezést sorol fel és definiál angol, francia és német nyelven (Lists of Key Onomastic Terms, 1. Icosweb Terminology). ${ }^{1}$

2.1. Az ICOS alapvető névtani terminusokat tartalmazó szójegyzéke. A 70 alapvető névtani terminust magában foglaló jegyzéket a munkacsoport tagjai angol nyelvre dolgozták ki. A szójegyzékben a terminusok formájának, jelentésének meghatározásán túl egyes szakkifejezések kapcsán illusztratív példákat is találunk. Néhány terminussal összefüggésben a jelentésre (pl. anthroponymy, hagionym, oronym), a formára ( $\mathrm{pl}$. metronym), a tulajdonnévi jellegre (pl. ethnonym, inhabitant name), illetve a használatra (pl. first name, odonym) vonatkozó megjegyzéseket, javaslatokat is olvashatunk. Más esetekben a terminusok alá-, fölé-, mellérendeltségi viszonyairól (hiponimák, hiperonimák, kohiponimák) tájékoztatják a szerkesztők az olvasót (1. pl. a nickname és a by-name, a street name és a hodonym, a choronym és a macrotoponym kapcsolatát); míg az utaló címszavak a szinonim terminusokról, illetve a terminusvariációkról nyújtanak információkat (1. pl. az animal name és zoonym, a minor name és microtoponym, a name bearer és denominatum esetét).

A szójegyzék francia és német nyelvü változata az angol terminuslista alapján készült, nem egészen azonos szemléletet alkalmazva. Míg a francia jegyzék a nemzeti nyelvü szakkifejezéseket előtérbe állító szükebb értelemben vett fordítása az angol terminuslistának, addig a német változat előbb megadja a nemzeti nyelvü szakkifejezés angol megfelelöjét, majd a terminus definíciója, illetve, ha van ilyen, a megjegyzés következik. A német változat néhánnyal több, nyelvspecifikus megjegyzést tartalmaz, mint az eredeti, angol glosszárium (1. pl. az Anthroponym, Appellativierung, Beiname, Mikrotoponym címszavakhoz füzött megjegyzéseket). A német szójegyzékben van továbbá néhány olyan, fơként német eredetủ utaló címszó is, amely mellett angol megfelelő nem szerepel, mivel azt a definícióval együtt a szinonim szakkifejezésnél találjuk meg a listában (1. pl. a Deckname, Gewässername, Kosename, Riedname utaló címszavakat).

Mind a francia, mind a német változat készítői szembesültek néhány jellemzö, a nyelvek közötti terminológiai munkát kísérő problémával: így esetenként választaniuk kellett a nemzetközi hátterü, illetve a nemzeti nyelvi eredetü terminus önálló szócikk címszavaként való alkalmazása között; kezelniük kellett a terminushiány és a terminustöbblet eseteit. A német változatban a fent említett utaló címszavak a nemzetközi jellegü szinonim szakkifejezések önálló szócikkeihez utalnak (azaz a Kryptonym, Hydronym, Hypokoristikon, Mikrotoponym címszavakkal felvezetett szócikkekhez), így a nemzetközi hátterủ terminusok némiképp előtérbe kerülnek a nemzeti nyelvi eredetüekkel szemben. Hasonló módon (önálló és utaló címszavak útján) kezeli a német szójegyzék azokat az eseteket is, amelyekben egy-egy angol terminusnak több német eredetü vagy több nemzetközi hátterü szakkifejezés feleltethető meg a német nyelvben (pl. nickname $=$ Neckname utaló és Spitzname önálló címszó; deonym = Epotoponym utaló és Deonym önálló címszó).

\footnotetext{
${ }^{1}$ Az ICOS hivatalos nyelvei. Az angol és a német glosszáriumban megtaláljuk továbbá a névtani terminológia 1961-2002 között kiadott művekből összeállított válogatott nemzetközi bibliográfiáját is.
} 
Különbségek figyelhetők meg a nyelvek között abban a tekintetben is, hogy egy-egy fogalom jelölésére hagyományosan hány szinonim értékü terminust használnak. A német szójegyzékben - amennyiben a szinonim szakkifejezések száma a német nyelvben kevesebb, mint az angolban - néhány német szakkifejezés mellé több angol megfelelő is került (pl. Familienname = family name, surname, last name önálló címszó és az ide vezető Zuname utaló címszó; Vorname = first name, given name önálló címszó és az ide vezető Taufname $=$ Christian name utaló címszó). A francia szójegyzékből, mivel abban angol megfelelőket nem találunk, egy-egy fogalom kapcsán a szinonim terminusok hiánya csak áttételesen deríthető ki (így pl. a nom de famille és a prénom kifejezésekre utaló címszó nincsen). Mind a német, mind a francia változat beilleszt egy-egy, az eredeti terminusjegyzékből hiányzó önálló szócikket (vö. a francia toponymiste és a német onymisch szócikkeit).

Az ICOS alapvető névtani terminusokat tartalmazó szójegyzéke sikeresen írja le a tárgyalt szakkifejezések tényleges használatával kapcsolatos jellemzöket; mutatja ezt az is, hogy a terminusjegyzék a szakemberek részéről megerősítésre talált. A névtani szakkifejezések e jegyzék szerinti használata az ICOS kiadványaiban, kongresszusain, valamint egyéb névtudományi témájú írásokban, konferenciákon egyre inkább kívánalomként fogalmazódik meg.

2.2. Az ICOS-terminusjegyzék magyar változata. A szójegyzék további nemzeti nyelvü változatainak elkészítésére való igény az ICOS Terminológiai Munkacsoportnak a téma iránt érdeklődő névkutatókkal kibővített, 2011. szeptember 6-i barcelonai ülésén nyilvánosan is megfogalmazódott, s a kívánalom megerösítést nyert a munkacsoport hasonló módon szervezett 2014. augusztus 26-i glasgow-i ülésén. Itt a jelenlévők vállalták, hogy gondoskodnak a terminusjegyzék anyanyelvükre való átdolgozásáról, közreadásáról. A glasgow-i megbeszélésen magyar részről Bölcskei Andrea, Farkas Tamás és Slíz Mariann vettek részt. Az ICOS alapvető névtani terminusokat tartalmazó szójegyzékének magyar változatát, a kapcsolódó magyar-angol mutatóval, valamint egy, az angolmagyar-német-francia terminusekvivalenciákat megadó négynyelvü jegyzékkel együtt Bölcskei Andrea szakmai felügyelete mellett Oláh Bence Attila egyetemi hallgató (KRE BTK, anglisztika alapképzés, fordítói-szaknyelvi specializáció, majd terminológia mesterképzés) készítette el 2015-ben.

A terminusjegyzék magyar változatának elkészítése során több, a fentiekhez hasonló, a nyelvek közötti terminológiai harmonizációt, a definíciók megfogalmazását, az illusztratív példák megválasztását, illetve a szójegyzék szerkezetének kialakítását érintő problémát kellett megoldani. A munka során alkalmazott alapelveket, szükség esetén példákkal illusztrálva, az alábbiakban mutatjuk be.

A magyar terminusjegyzék, akárcsak a német és a francia változatok, az eredeti, angol nyelvü glosszárium alapján készült. A szójegyzék szerkezetét tekintve az volt a cél, hogy feltüntessük az angol-magyar terminusekvivalenciákat; megtartsuk az önálló és utaló szócikkeknek az eredeti glosszáriumban alkalmazott rendszerét; továbbá hogy a jegyzék formailag és tartalmilag illeszkedjen a szintén e kötetben közreadott, földrajzinévegységesítési szakkifejezéseket taglaló UNGEGN-listához (1. lent). A szócikkek felépítését ezért a következőképpen alakítottuk ki: a szócikk sorszámát az angol terminus követi címszóként, ezután megadjuk a magyar terminusekvivalenciá(ka)t, végül önálló szócikk esetében a definíció, utaló szócikk esetében pedig az utalás következik. Ennek megfelelően 
a szócikkek sorrendjét - a német és a francia változattal szemben, ám az UNGEGNlistának megfelelően - az angol terminusok betürendje, azaz az eredeti angol szójegyzék szócikkeinek sorrendje szabja meg.

Az angol terminus magyar megfelelőjének, illetve megfelelőinek a megadásakor előnyben részesítettük a hagyományosan elterjedt, főként nemzeti nyelvi eredetű szakkifejezéseket; az ezek mellett sokszor inkább csak újabban jelentkező nemzetközi hátterü terminusokat zárójelben tüntettük fel a megfelelő magyar eredetü szakkifejezés mögött; pl. 01 névváltozat (= allonima); ${ }^{2} 19$ népnév (= etnonima); 27 szentnév (= hagionima); 29 víznév (= hidronima); 68 helynév (= toponima). Amennyiben a magyar nyelvben csak a nemzetközi jellegü terminus használata vált gyakorlattá, értelemszerüen ezt a megfelelést adtuk meg (pl. 16 endonima, 20 exonima, 33 makrotoponima, 35 mikrotopomina). A nemzetközi hátterü magyar terminusokat - a hasonló eredetü angol szakkifejezések alakjától függetlenül - a hazai szaknyelvben meghonosodott formájukban rögzítettük, pl. 13 denominatum = megnevezett (= denotátum). Ha az angol terminusnak pontosan megfeleltethetö magyar ekvivalenst nem találtunk, a nemzetközi hátterü terminus magyaros formáját tüntettük fel (pl. 10 koronima, 18 ergonima), illetve megfelelö magyar eredetü terminust dolgoztunk ki (pl. 09 informális név, 42 szigetnév), esetenként a két eljárást kombináltuk, pl. 34 anyanévi eredetü név (= matronimikum, metronimikon); 53 apanévi eredetü név (= patronimikum, patronimikon). Amennyiben a nemzetközi hátterü angol szakkifejezésnek megfelelö magyar elem önállóan nem, ám magyar terminusok alkotóelemeként előfordul nyelvünkben, ezt jelöltük (pl. 49 -onima utótag).

Az angol-magyar terminusekvivalenciák megítélésekor a szakkifejezések által jelölt fogalmak (szemléleti) azonosságát vettük alapul, pl. 22 first name és 24 forename = utónév (névelemek sorrendje); 21 family name = családnév (funkció), 32 last name és 64 surname $=$ vezetéknév (névelemek sorrendje). Az azonos terminusalkotó elemek révén összetartozó angol szakkifejezéseket, ahol erre mód volt, hasonló felépítésü magyar megfelelökkel törekedtünk visszaadni, pl. 67 toponomastics = helynévkutatás, helynévtan (= toponomasztika), 68 toponym = helynév (= toponima) és 69 toponymy = helynévállomány. A magyar terminusok hagyományosan kialakult alá-, fölé- és mellérendeltségi viszonyait igyekeztünk tükröztetni, megtartani (pl. 09 informális név és alkategóriája, a 43 ragadványnév; 68 helynév [= toponima] és egyes esetekben szinonimája, a 25 földrajzi név). (Magyar eredetü és nemzetközi hátterü névtani terminusaink kérdéseinek elvi vonatkozásaihoz 1 . FARKAS 2012; a magyar névtani terminusok keletkezésének és változásának tényezőihez 1. SLÍz 2012.)

Az önálló szócikkek definíciói az eredeti meghatározásokat követik tartalmilag és formailag egyaránt, azaz a jelentés megadását esetenként illusztratív példák bemutatása követi, és ha szükséges, megjegyzések alkalmazására is sor kerül. Az utaló szócikkek a jelentést megadó önálló szócikkek angol és magyar címszavát, valamint zárójelben a szócikk jegyzékbeli sorszámát közlik. Az illusztratív példák többnyire szintén az eredeti angol szövegből származnak (pl. a 09 informális név, a 31 lakossági név, a 43 ragadványnév esetében), néhol magyar példákkal is kiegészítve (pl. a 30 becenév, a 35 mikrotoponima, a 63 utcanév esetében); ám egyes terminusok kapcsán a helyes értelmezés érdekében

\footnotetext{
${ }^{2}$ A terminus előtt annak a szócikknek a sorszáma áll, amelyben a kérdéses szakkifejezés a magyar szójegyzékben megtalálható.
} 
az eredeti példáktól eltérő, de funkciójukban azoknak megfelelő magyar nevek kizárólagos alkalmazása mutatkozott célszerünek (pl. a 22 utónév esetében). Az eredeti terminusjegyzék jelentésre (pl. 69 helynévállomány, 27 szentnév [= hagionima], 52 hegynév [= oronima]), formára (pl. 34 anyanévi eredetü név [= matronimikum, metronimikon]), tulajdonnévi jellegre (pl. 19 népnév [= etnonima], 31 lakossági név), használatra (pl. 10 koronima, 14 köznevesült tulajdonnév, 68 helynév [= toponima]) vonatkozó megjegyzéseit, javaslatait megtartottuk; sőt, néhány esetben az angol, illetve a magyar terminus értelmezésének, használatának a jellemzőire utaló saját megjegyzést is beillesztettünk (pl. 22 utónév, 49 -onima [utótag]). A megjegyzéseket a definíció részének tekintettük, a szócikkekben külön egységként való megjelenítésüket nem tartottuk szükségesnek.

A magyar terminusok szerinti kereshetőséget biztosítja a magyar-angol mutató. A mutató első oszlopában a magyar terminusok szerepelnek betürendben; az összetett szakkifejezések - az UNGEGN-lista mutatójának gyakorlatát követve - elö- és utótagjuk szerint is be vannak sorolva (pl. személynévállomány és állomány, személynév-; dülőnév és név, dülö-); a szinonim terminusok minden lehetséges sorrendben elöfordulnak, a szinonimitás jelölésével; pl. allonima (= névváltozat), névváltozat (=allonima) és változat, név- (= allonima). A második oszlopban a magyar terminus(ok)nak megfelelö angol szakkifejezést találjuk. Ha a magyar terminus(ok)nak több angol nyelvü ekvivalenciája is ismeretes az ICOS-jegyzék alapján, valamennyit feltüntetjük minden alkalommal, pl. helynév (= toponima), név, hely- (= toponima), toponima (= helynév) $\rightarrow$ place name toponym. A mutató harmadik oszlopában a magyar terminus(oka)t tartalmazó önálló vagy utaló szócikkeknek a sorszámát adtuk meg.

Az angol-magyar-német-francia terminusekvivalenciákat megadó négynyelvü jegyzékben az önálló vagy utaló szócikkek címszavaiként álló, valamint a megjegyzésekben előkerülő terminusok kaptak helyet. A terminusok angol-német megfeleléseinek az azonosítása nem jelentett különösebb problémát, mivel a német szakkifejezések angol ekvivalensei a szójegyzék német változatában többnyire fel vannak tüntetve. Az angol ekvivalens nélkül felvett néhány német terminus utaló szócikk címszava, így ezeket a megfelelö, az angol terminust közlö önálló szócikk címszava mögött, zárójelben tüntettük fel a négynyelvü jegyzékben; pl. Hydronym (= Gewässername), Hypokoristikon (=Kosename). A francia terminusok angol ekvivalenseinek az azonosítását a definíciók angol és francia szójegyzékbeli szövegének, illetve az illusztratív példáknak az összevetése tette lehetővé. Ha a francia szójegyzék több, szinonim angol szakkifejezésre egyetlen francia ekvivalenciát adott meg, ezt a terminust írtuk be valamennyi kérdéses angol müszóhoz, pl. microtoponym, minor name $\rightarrow$ microtoponyme; Christian name, first name, forename, given name $\rightarrow$ prénom. Az eredeti angol glosszárium anyagához mérten többletként jelentkező egy-egy német, illetve francia szócikk címszavát pedig rövid magyarázattal ellátva, az értelmileg hozzá legközelebb eső megfelelő nyelvű terminus mellett adtuk meg, vö. német „Onym (melléknévi formája: onymisch)”; francia „onomasticien (helynevek vonatkozásában: toponymiste)”.

3. Az UNGEGN föbb törekvései. Az UNGEGN az ENSZ Gazdasági és Szociális Tanácsán (UN Economic and Social Council; ECOSOC) belül működő hét állandó szakértői testület egyike. A szervezet 1959-ben kezdte meg müködését előbb ideiglenes, majd 1973 óta állandó bizottságként. Jelenleg több mint 100 országból mintegy 400 tagja van, főként földrajztudósok, térképészek, nyelvészek, történészek, földmérők és az 
államigazgatásban dolgozó szakemberek. Az UNGEGN feladatai közé tartozik a nemzetközi helynév-standardizációs tevékenység népszerüsítése, irányítása; a földrajzi nevek egységesítésével kapcsolatos terminológiai kérdések tisztázása; a hivatalos helynévalkotással összefüggő irányelvek megfogalmazása; a latin betüs helynévírás egységes elveinek kidolgozása; a nemzeti névtestületek felállításának és hatékony müködésének ösztönzése; a már egységesített földrajzi nevek vonatkozásában a névinformációk gyüjtése, az adatok tárolása, karbantartása és terjesztése; helységnévtárak, földrajzinév-adatbázisok létrehozása; a helynév-standardizációval összefüggő oktatás biztosítása. A szakértői testület a hivatalos, írásbeli földrajzi nevek nemzetközi egységesítését az e téren elért nemzeti eredményekre építi; döntéseit, a szabványosítás gyakorlatának megfelelően, konszenzus útján hozza; az UNGEGN szervezeti felépítéséről, földrajzinév-egységesítési alapelveiröl, helynév-standardizációs modelljéről 1. BÖLCSKEI 2012a.).

Az UNGEGN a helynév-standardizáció egyes országokban való eredményes megvalósításához a kérdéskört elméleti és gyakorlati oldalról tárgyaló kézikönyvek kiadásával is hozzájárul. A Manual for the National Standardization of Geographical Names címü kiadvány (Manual 2006) egy, a földrajzi nevek nemzeti egységesítésében jó eredményeket elért tagországok által alkalmazott „legjobb gyakorlatok” alapján kialakított standardizációs modell részletes leírását tartalmazza; míg a Technical reference manual for the standardization of geographical names címü kézikönyv (Manual 2007) gyakorlati segítséget nyújt a nem betüírást alkalmazó, illetve a nem latin ábécét használó nyelvek helyneveinek latin betüs átírása, a helynévi adatok pontos nemzetközi átadása, valamint a világ országainak hivatalos angol és helyi megnevezései vonatkozásában.

3.1. Terminológiai munkálatok az UNGEGN-ben és a földrajzinév-egységesítéssel kapcsolatos szakkifejezéseket közreadó terminológiai szójegyzék. A fent említett két kézikönyv kiadását megelőzte egy, a helynév-standardizáció során gyakran használatos terminusokat összegyüjtő és definiáló szójegyzék elkészítése, amely az ENSZ hat hivatalos nyelvén (angol, arab, francia, kínai, orosz, spanyol) jelent meg, s amely a kézikönyvek terminushasználatának alapjául szolgált (UNGEGN Glossary).

E szójegyzék előzménye a H. A. G. LEWIS által szerkesztett, 1984-ben kiadott Glossary No. 330: Technical Terminology Employed in the Standardization of Geographical Names [Szójegyzék No. 330: A földrajzi nevek egységesítésében használt szakkifejezések] címü terminusgyüjtemény volt, amely 115, a témához kapcsolódó fogalom megjelölésére összesen 175 szakkifejezést sorolt fel és határozott meg az említett hat nyelven. Javított változatát Glossary No. 330/Rev² jelzés és változatlan cím alatt 1987-ben tették közzé (RAPER 2000: 194, KERFOOT 2000: 205). E terminusgyüjteménynek FÖLDI ERVIN jóvoltából magyar fordítása is készült, amely a Névtani Értesítőben jelent meg, az ENSZ földrajzinév-egységesítési tevékenységének gyakorlatát bemutató tanulmánnyal együtt (1992a, 1992b). Az UNGEGN 1989. évi 14. ülése ugyanakkor a hatnyelvü jegyzék javításának szükségességéről határozott, mivel az a téma szempontjából nem volt teljesnek ítélhető, több ismétlődést is tartalmazott, a definíciók pedig nem érintették a nem latin betüs írásrendszerek és a nem európai nyelvek sajátosságait.

Az UNGEGN ekkor egy, a helynév-standardizáció terminológiájával foglalkozó munkacsoport létrehozását kezdeményezte, az izraeli Naftali Kadmon irányításával, aki a szójegyzék megújítását célzó munkálatok vezetésére is vállalkozott. A terminológiai munkacsoport 1991-ben, az UNGEGN 15. ülésén mutatta be a készülő új szójegyzék 
első változatát, amely 336 terminust és definíciót tartalmazott angol nyelven, helynévi példái pedig már 16 nyelvből, illetve írásrendszerből származtak. 1992-ben, a földrajzi nevek egységesítésével foglalkozó hatodik ENSZ-konferencián (United Nations Conference on the Standardization of Geographical Names; UNCSGN) a résztvevők a terminológiai munkacsoport fenntartásáról döntöttek, s feladatául egy, az ENSZ hivatalos nyelvein elérhető helynév-standardizációs terminológiai szótár elkészítését, a későbbiek során pedig annak rendszeres felülvizsgálatát és karbantartását jelölték ki. A munkacsoport 1998-ban, a hetedik UNCSGN-konferencián nyújtotta be a szójegyzék újabb és bővebb változatát. A 375 terminust tartalmazó, hatnyelvü változat mint UNGEGN-dokumentum az ENSZ Gazdasági és Szociális Ügyek Főosztálya Statisztikai Részlege (UN Department of Economic and Social Affairs Statistics Division) kiadványaként 2002-ben jelent meg New Yorkban (GTSGN.). E kiadvány főszerkesztője NAFTALI KADMON volt; a szójegyzék összeállításában, fordításában pedig az UNGEGN földrajzinév-egységesítési terminológiával foglalkozó munkacsoportjának tagjai segédkeztek önkéntes alapon.

A munkacsoport további kötelezettsége maradt a szójegyzék folyamatos korszerüsítése a tudományos szemlélet, valamint a nyelv változása függvényében. Ennek jegyében született meg a 2007-ben kiadott függelék, az Addendum (AGTSGN.), amely hat, korábban már meghatározott terminus új definícióját, valamint tizenhét újonnan definiált terminust közöl angol nyelven; valamint elkészült az Addendum anyagának fordítása is az ENSZ valamennyi hivatalos nyelvére. Az UNGEGN honlapján jelenleg a 2002-es szójegyzék és a 2007-es függelék egybeszerkesztésével született 2015-ös kiadványváltozat található meg pdf formátumban (UNGEGN Glossary). (A szójegyzék és a függelék anyagának nyelvészeti szempontú áttekintését 1. BÖLCSKEI 2012b.)

A szójegyzéknek az ENSZ hat hivatalos nyelvén kiadott változatán túl több, egyéb nemzeti nyelvü adaptációja is elkészült, pl. német (JORDAN-BEINSTEIN 2011), lengyel (ŁUKASIK ford. 2014); a 2012-ben megjelent koreai kiadvány pedig az UNGEGN honlapjáról is letölthető (UNGEGN Glossary Korean).

Összességében a terminológiai munkacsoport tevékenysége egyrészt erősen kapcsolódik az UNGEGN azon felismeréséhez, hogy fö törekvéseinek sikeres megvalósításához alapvető feltétel a földrajzi nevek egységesítésével kapcsolatos szabványosított és harmonizált terminológia bevezetése, használatának támogatása (UNGEGN Brochure); másrészt összhangban áll az újabban más tudományágakban is egyre hangsúlyosabban jelentkező nemzetközi terminológiai egységesítési gyakorlattal. 2008 óta a munkacsoport, melynek jelenlegi vezetője a svéd Staffan Nyström, részben a személyi átfedéseknek köszönhetően eredményesen müködik együtt az ICOS terminológiai munkacsoportjával is (1. NYSTRÖM 2014).

3.2. Az UNGEGN-szójegyzék magyar változata. Az UNGEGN helynév-standardizációs terminológiai szójegyzékének magyar változata, pontosabban annak első verziója a Károli Gáspár Református Egyetem Magyar Nyelvtudományi Tanszékén készült el 2013-ban, projektmunka keretében (projektvezető: Bölcskei Andrea), terminológia mesterszakos hallgatók (Miklódy Dóra, Horváth Ágnes, Nagy Ilona Erzsébet, Sajermann Zsófia Szonja és Varga Julianna) bevonásával (vö. BöLCSKEI 2013a), hogy a lektorálás után a magyar nyelvü földrajzi nevek egységesítésének anyaországbeli és határon túli gyakorlatát segítse (az utóbbi kérdésről vö. SZABÓMIHÁLY 2007, 2009, 2013; CSOMORTÁNI 2014). 
Munkánk során figyelembe kellett vennünk, hogy az eredeti szójegyzék egy meglehetősen összetett terminológiai alapelv (vö. BUDIN 2001: 14-17) megvalósítására törekszik, s földrajzi és nyelvi kötöttségektől mentesen igyekszik a szakmai kommunikáció terminológiai problémáit megoldani: olyan elméleti keretet biztosít, amelyet a szakértők könnyen megoszthatnak egymással, s amelyet ki-ki a saját vagy az általa képviselt igényeknek, nyelv(ek)nek, anyanyelvnek megfelelően tovább alakíthat. A készítők - korszerü terminográfiai elveket alkalmazva (vö. CABRÉ 2003: 183) - a terminológiai egységeket ezért kognitív, nyelvi és kommunikatív összetevőik bemutatása mentén írták le. A magyar változat elkészítésekor feladatunk tehát kettős volt: meg kellett őriznünk az eredeti glosszárium szemléletét, de anyanyelvünk sajátosságaihoz, terminushasználatának gyakorlatához kellett igazítanunk annak anyagát.

Az UNGEGN-szójegyzék magyar változatának elkészítése során alkalmazott alapelvek nem térnek el az ICOS-terminuslista magyar változatának kialakítása kapcsán fent már ismertetettektől. Részletezve: az angol terminus magyar ekvivalensének, ekvivalenseinek a megadásakor a magyarosság és a nemzetközi érthetőség követelményének az összeegyeztetésére törekedtünk, ezért amennyiben létezik, a hagyományos használatú magyar eredetü müszót tüntettük fel elsődleges megfelelönek, s mellette zárójelben, egyenlőségjel után adtuk meg az azonos jelentésű nemzetközi hátterü magyar szakkifejezést, pl. 017 személynév (= antroponima), 021 kétnyelvüség (= bilingvizmus), 064 mellékjel (= diakritikus jel), 129 útnév (= hodonima). Fordított sorrenddel azokban az esetekben éltünk, amikor az idegen hátterü magyar terminus jóval gyakrabban jelentkezik a megfelelö szaknyelvi regiszterben, mint magyar eredetü megfelelöje, pl. 007 allofón (= hangváltozat), 099 firmware (= belsö vezérlöprogram), 171 ligatúra (= ikerbetü).

Amennyiben nyelvünkben csak a magyar eredetü (pl. 280 latin betüs átírás), illetve csak a nemzetközi hátterü terminusok váltak elterjedtté (pl. 047 kreol, 142 interfész), természetesen azokat írtuk be ekvivalensként. A hiányzónak vélt magyar terminusekvivalenciákat fordítás (pl. 104 full title $\rightarrow$ teljes megnevezés, 299 short form [of a name] $\rightarrow$ rövid névforma) útján kidolgozott, illetve a nemzetközi hátterü terminus magyaros formájának kialakításával létrehozott (pl. B118 geonym $\rightarrow$ geonima), esetenként a két típusú megközelítés kombinálásával megalkotott (pl. 277 retranszkripció [= kiejtés szerinti átírás visszaalakítása], 278 retranszliteráció [= betü szerinti átírás visszaalakitása]) szakkifejezésekkel pótoltuk. Az angol főnév/melléknév + fönév szerkezetü terminusok esetében, mivel ezek mögött többféle grammatikai, szemantikai viszony is meghúzódhat, sokszor célszerünek mutatkozott az angol müszónál jóval kifejtettebb magyar szakkifejezést kidolgozni a definíció tükrében, pl. 372 vowel marker = magánhangzójelölö kiegészítö írásjegy; 015 alphabetic sequence rules = betürendet meghatározó szabályok; 342 toponymic guidelines = helynév-egységesitési irányelvek.

Az angol-magyar terminusekvivalenciák azonosításakor számításba kellett vennünk, hogy az egyes nyelvek lexikálisan másként oszthatják fel a valóságot, ezért a szakkifejezések sem mindig pontos megfelelöi egymásnak (vö. KLAUDY 1997²: 117). Van példa arra, hogy egy angol terminus, a jelentés függvényében, két különböző magyar terminusekvivalenssel rendelkezik, pl. 344 toponymy = (a) helynévtan, helynévkutatás (= toponomasztika); illetve (b) helynévállomány. Más esetben két azonos jelentésü, ám formájában (részben) különböző angol szakkifejezésnek egy magyar terminusekvivalens feleltethető meg, pl. 269 proper name és 270 proper noun = tulajdonnév; 032 composite name és 033 compound name = összetett név; 185 man-made feature és 048 cultural feature = 
mesterséges alakulat; 265 place name index és 343 toponymic index = helynévmutató. Néhány alkalommal a szinonim angol terminusoknak rokon értelmű magyar terminusekvivalensei akadnak, pl. 173 linguistic area = nyelvterület és 175 linguistic region = nyelvi régió. Az is megesik, hogy egy egynemünek tekintett fogalmat jelölő angol müszónak létezik ugyan magyar megfelelője, ám ez nyelvünkben két terminus hiperonimája; ezt csak a definíció szintjén érzékeltethettük, pl. 001 acronym $\rightarrow$ mozaikszó (= akronima): a betüszó és a szóösszevonás összefoglaló megjelölése.

A szakirodalomból nyert, egymással azonos értékben használt angol és magyar terminusok időnként erősen eltérő szemléletet tükröznek, pl. 110 generic element $\rightarrow$ földrajzi köznévi elem, 112 generic term = földrajzi köznév. Találunk anyagunkban ún. „hamis barát” terminusokat is, pl. 003 allograph = allográf (= iráselem-változat, betüváltozat), nem pedig más által írott (vö. allográf végrendelet); 005 allonym = névváltozat (= allonima), nem pedig álnév; 368 vocalization = magánhangzó-jelölés, nem pedig vokalizáció. A megfelelö magyar terminus azonosításában, megalkotásában fontos szerepük lehet a definícióban foglaltaknak, pl. 092 feature, natural=alakulat, természetes: ,$\rightarrow$ Topográfiai alakulat, amelyet nem ember hozott létre, és lényegesen nem is módosított”; 093 feature, physical = alakulat, természeti: „Bármely olyan $\rightarrow$ topográfiai alakulat, amely vizuálisan észlelhető". A többféle formában is jelentkező magyar terminusok esetében a gyakrabban használatos alakot vettük fel a szójegyzékbe; pl. 364 vektoros mód, nem pedig vektormód.

Törekedtünk az eredeti terminuscsoportok megfelelő módon való visszaadására, így pl. a -gram $\rightarrow$-gram $\sim$-gramma 'jel' utótagú vagy a script $\rightarrow$ írás, írásrendszer elemet tartalmazó szakkifejezések esetében, pl. 257 phonogram $\rightarrow$ fonogramma (= hangjel), 134 ideogram $\rightarrow$ ideogramma (= képírásjel), 179 logogram $\rightarrow$ logogram (= szójel), 326 syllabogram $\rightarrow$ szillabogram (= szótagjel); illetve 061 defective alphabetic script $\rightarrow$ hiányos betüirás, 075 donor script $\rightarrow$ átadó írás, 182 logographic script $\rightarrow$ szójelölö irás, 208 multiscriptual map $\rightarrow$ több irásrendszerü térkép, 189 map script $\rightarrow$ térképi irás.

Az önálló szócikkek esetében igyekeztünk megtartani a definícióknak az eredeti szójegyzékben fellelhető értelmi és formai összefüggéseit (pl. a kapcsolódó címszavakra való szövegbeli utalások rendszere; a jelentések logikai kapcsolatait taglaló, egymást magyarázó, illetve párhuzamos megfogalmazású definíciók esetei); valamint törekedtünk arra, hogy megőrizzük a meghatározások mögött lévő szemléletet (pl. a szaktudományokban bevett meghatározásokhoz képest általánosabb vagy részletezőbb jellegü definíciók). A definíciók megfogalmazása során a megfelelő szakszókincs megismerése és alkalmazása vonatkozásában fontos tényezőnek mutatkozott bizonyos, elsősorban nyelvtudományi, földrajztudományi, térképészeti és számítástechnikai háttérismeretek megléte, illetve az ezek megszerzésére való képesség. Az utaló szócikkek a jelentést megadó önálló szócikkek angol címszavát, valamint zárójelben a szócikk jegyzékbeli sorszámát közlik a definíció helyén.

Az illusztratív névpéldák tekintetében azok jellegének és szócikkbeli szerepének megfelelöen különféle eljárásokkal éltünk. Bizonyos esetekben az angol anyagban megadott formában volt indokolt megtartani a helyneveket, pl. Kaapstad és Cape Town a 228 név, egységesitett ( = standardizált) terminus jelentését megvilágító példaként. Máskor az eredeti nyelvü helynévforma mellett zárójelben a magyar alak is megadható volt a tárgyalt jelenség bemutatására, pl. Al-Mamlakah al-Hāshimīyah al-Urdunīyah (Jordán Hásimita Királyság) a 183 teljes névforma példájaként. Néhol célszerü volt a névpéldákhoz 
szöveges magyarázatot füzni, pl. az A240 helynév (= toponima) alanyesete szócikk esetében; magyar nyelvü adatokkal szaporítani az eredeti példaanyagot, pl. a 081 exonima szócikk esetében; illetve az eltérő nyelvi sajátosságok miatt magyar példával kiváltani az eredeti kifejezést, pl. a 201 morféma szócikk esetében.

A szójegyzék magyar változatának formai sajátosságait az eredeti kiadvány nem angol nyelvű terminuslistáinak gyakorlata nyomán alakítottuk ki. A szócikkek a magyar változatban is sorszámmal kezdődnek, ezután következik címszóként az angol terminus, majd a magyar terminusekvivalenciá(k), végül pedig a definíció, illetve az utalás. A szócikkek sorrendje tehát, mint a többi, idegen nyelvű szójegyzék esetében is, az angol címszavak betürendje szerint alakul. A könnyebb kezelhetőségre törekedve az Addendumban szereplő új definíciókat adtuk meg a hat, újra definiált szakkifejezés meghatározásaként, a 2007-ben újonnan felvett terminusokat pedig a 2002-es lista megfelelő helyére illesztettük be. Az angol nyelvü szójegyzék szemléletének megfelelően a több tagból álló terminusokat első és második elemük szerint is listáztuk, fő-, illetve utaló címszóként, a hasonló módon kezelt magyar terminusekvivalensekkel együtt. Az eredeti szójegyzék angol terminushasználatra vonatkozó megjegyzéseit, mivel maguk az angol terminusok is a jegyzék részét képezik, megfelelő magyarázat kíséretében átemeltük. A magyar terminusok visszakereshetőségét a szójegyzék végén található magyar-angol betürendes mutató biztosítja. (A szójegyzék magyar változatának készítésekor alkalmazott alapelvek részletezőbb kifejtését a még lektorálás előtt álló változat vonatkozásában 1. BÖLCSKEI 2013b.).

A magyar szöveg az angol nyelvü szójegyzék alapján készült, de a magyar változatot lektorok segítségével összevetettük a francia (Vitányi Borbála), a spanyol (Tóth Mária) és az orosz (Slíz Mariann) nyelvü anyaggal is. A definíciók szakszerüségének és az angol-magyar viszonylatban megvalósított terminusharmonizáció megfelelőségének az ellenőrzésére szakembereket kértünk fel a nyelvészet (B. Papp Eszter, LEG Magyarország Zrt.; Mikesy Gábor, FÖMI), a földrajz (Tiner Tibor, MTA Csillagászati és Földtudományi Kutatóközpont Földrajztudományi Intézet), a térképészet (Márton Mátyás, ELTE Térképtudományi és Geoinformatikai Tanszék), a müszaki tudományok, a számítástechnika (Kovács László, TÉK Localizations Kft.) és a szakközgazdaság (Perger Imre, MÁV-START Zrt.) területéröl; egyeztettünk továbbá közigazgatási szakmai tanácsadóval is (Győrpál Elemér, Belügyminisztérium Önkormányzati Főosztály). A szakemberek javításait, megjegyzéseit indokolt esetben beépítettük a szövegbe, s ezt a változatot juttattuk el végső lektorálásra Földi Ervinnek (a magyar Földrajzinév-bizottság korábbi elnökének) és Pokoly Bélának (vezető tanácsadó, Földrajzinév-bizottság), akik az UNGEGN tevékenységének egykor, illetve jelenleg is aktív részeseiként alapos tudással rendelkeznek a témakört illetően (l. fent). A szójegyzék a jelenlegi formáját az általuk javasolt módosítások javának végrehajtása után nyerte el. A terminusjegyzék magyar változatának e kötetbeli megjelentetésére az ENSZ megfelelő bizottságának (Publications Board and Exhibits Committee) titkárától 2015. június 12-én kaptuk meg az engedélyt.

4. Összegzés. Mind az ICOS-jegyzék, mind pedig az UNGEGN-glosszárium magyar változatának az elkészítése során igyekeztünk ötvözni a tudományos pontosságot, a közérthetőséget, a forrásként használt dokumentumok anyagának, szemléletének tiszteletben tartását, a megfelelö magyar szaknyelvi regiszterek terminushasználatában megfigyelhető sajátosságok követését és a gyakorlati célszerüséget. A két terminusjegyzéket 
a kapcsolódó mutatókkal együtt az alábbiakban adjuk közre, abban a reményben, hogy a szakemberek, valamint a téma iránt érdeklődők számára egyaránt eredménnyel és könnyen használhatók lesznek.

\section{Hivatkozott honlapok}

AGTSGN. 2007. = KADMON, NAFTALI ed., Addendum for Glossary of Terms for the Standardization of Geographical Names. ST/ESA/STAT/SER.M/85/Add.1. United Nations, New York. https:// unstats.un.org/unsd/geoinfo/UNGEGN/docs/pubs/glossary add e.pdf

Glossary No. 330/Rev ${ }^{2}=$ Technical Terminology Employed in the Standardization of Geographical Names. ST/CS/SER.F/330/Rev.2. United Nations, 1987. http://unstats.un.org/unsd/geoinfo/ UNGEGN/docs/pubs/ST CS SER.F 330 Rev.2.pdf

GTSGN. 2002. = KADMON, NAFTALI ed., Glossary of Terms for the Standardization of Geographical Names. ST/ESA/STAT/SER.M/85. United Nations, New York. http://unstats.un.org/unsd/geoinfo/ UNGEGN/docs/glossary.pdf

Icosweb $=$ https://www.icosweb.net/drupal/

Icosweb Terminology $=\underline{\text { https://icosweb.net/drupal/terminology }}$

Jordan, Peter - Beinstein, Bernd 2011. German Glossary of Toponymic Terminology, Third Edition. Twenty-sixth UNGEGN session, Vienna. http://unstats.un.org/unsd/geoinfo/UNGEGN/ docs/26th-gegn-docs/WP/WP66_Glossary.pdf

ŁUKASIK, MAREK ford. 2014. Stownik terminów używanych przy standaryzacji nazw geograficznych. Główny Urząd Geodezji i Kartografii, Warszawa. http://ksng.gugik.gov.pl/english/wydawnictwa.php

Manual 2006. = United Nations Group of Experts on Geographical Names ed., Manual for the national standardization of geographical names. ST/ESA/STAT/SER.M/88. Economic \& Social Affairs. United Nations, New York. http://unstats.un.org/unsd/publication/seriesm/seriesm 88e.pdf

Manual 2007. = United Nations Group of Experts on Geographical Names ed., Technical reference manual for the standardization of geographical names. ST/ESA/STAT/SER.M/87. Economic \& Social Affairs. United Nations, New York. http://unstats.un.org/unsd/geoinfo/UNGEGN/docs/ pubs/UNGEGN\%20tech\%20ref\%20manual_m87_combined.pdf

UNGEGN Brochure $=$ http://unstats.un.org/unsd/geoinfo/UNGEGN/docs/pubs/UNGEGNbrochure en.pdf

UNGEGN Bulletin 35 = http://unstats.un.org/unsd/geoinfo/UNGEGN/docs/Bulletin/ungegnbulletin35.pdf

UNGEGN Glossary = KADMON, NAFTALI ed., Glossary of Terms for the Standardization of Geographical Names (Revised). http://unstats.un.org/unsd/geoinfo/UNGEGN/docs/pdf/Glossary of terms revised.pdf

UNGEGN Glossary Korean =지명 표준화를 위한 용어사전 Glossary of Terms for the Standardization of Geographical Names. National Geographic Information Institute, Republic of Korea. http://unstats.un.org/unsd/geoinfo/UNGEGN/docs/pdf/Glossary final.pdf

\section{Hivatkozott irodalom}

BÖLCSKEI ANDREA 2012a. Helynevek standardizációja: alapelvek, terminológiai kérdések a nemzetközi és a magyar gyakorlatban. Helynévtörténeti Tanulmányok 7: 85-102.

BÖlCSKEI ANDREA 2012b. A helynév-standardizáció terminológiájáról. Névtani Értesitő 34: 167-178.

BÖLCSKEI ANDREA 2013a. Az „UNGEGN Glossary of Terms for the Standardization of Geographical Names” címü terminusjegyzék magyar változatának elkészítéséről. Névtani Értesitő 35: 11-21. 
BÖLCSKEI, ANDREA 2013b. Challenges in updating the Hungarian terminology for geographical names standardization. Magyar Terminológia 6/2: 153-168. https://doi.org/10.1556/1206.2013.6.2.3

BUDIN, GERHARD 2001. A critical evaluation of the state-of-the-art of terminology theory. ITTF Journal 12/1-2: 7-23.

CABrÉ, TeResa 2003. Theories of Terminology: their description, prescription and explanation. Terminology 9/2: 163-199. https://doi.org/10.1075/term.9.2.03cab

CSOMORTÁNI MAGDOLNA 2014. A romániai magyar kisebbségi helységnév a nyelvi tervezés érdeklődési körében. Névtani Értesitö 36: 81-93.

FARKAS TAMÁS 2012. Szempontok a magyar névtani terminológia megítéléséhez. Névtani Értesitő 34: 139-148.

FARKAS TAMÁS 2015. A nemzetközi névkutatás és magyar kapcsolatai. In: FARKAS TAMÁS - SLíz MARIANN szerk., Magyar névkutatás a 21. század elején. Magyar Nyelvtudományi Társaság ELTE Magyar Nyelvtudományi és Finnugor Intézet, Budapest. 23-47.

FöLDI ERVIN 1992a. Az ENSZ földrajzinév-egységesítési tevékenysége. Névtani Értesitő 14: 21-35.

FÖLDI ERVIN 1992b. ENSZ földrajzinév-egységesítési szakkifejezések szótára. Névtani Értesitő 14: $127-138$.

Harvalí, Milan 2005. Towards a new millennium - towards a common onomastic terminology? In: Brylla, Eva - Wahlberg, Mats eds., Proceedings of the 21st International Congress of Onomastic Sciences. Uppsala 19-24 August 2002. Språk- och folkminnesinstitutet, Uppsala. 1: $160-171$.

Harvalík, Milan 2014. Towards a common onomastic terminology? The next step. In: TORT I Donada, Joan - Montagut i Montagut, Montserrat eds., Els noms en la vida quotidiana. Actes del XXIV Congrés Internacional d'ICOS sobre Ciències Onomàstiques. / Names in daily life. Proceedings of the XXIV ICOS International Congress of Onomastic Sciences. Biblioteca Tècnica De Política Lingüística 11. Generalitat de Catalunya, Barcelona. 21-25. http://www.gencat. cat/llengua/BTPL/ICOS2011/004.pdf és https://doi.org/10.2436/15.8040.01.4

Kerfoot, HeLen 2000. Wien or Vienna; Kalaallit Nunaat, Grønland or Greenland? Recent work and directions in geographical names standardization through the United Nations. Onoma 35: 199-213.

KLAUDY KINGA $1997^{3}$. A forditás elmélete és gyakorlata. Angol, német, francia, orosz forditástechnikai példatárral. 3., átdolgozott, bővített kiadás. Scholastica, Budapest.

NYSTRÖM, STAFFAN 2014. The terminological work of UNGEGN and ICOS - a presentation and a comparison. In: TORT I DONADA, JOAN - MONTAGUT I MONTAGUt, MONTSERRAT eds., Els noms en la vida quotidiana. Actes del XXIV Congrés Internacional d'ICOS sobre Ciències Onomàstiques. / Names in daily life. Proceedings of the XXIV ICOS International Congress of Onomastic Sciences. Biblioteca Tècnica De Política Lingüística 11. Generalitat de Catalunya, Barcelona. 52-57. http://www.gencat.cat/llengua/BTPL/ICOS2011/008.pdf\%20 és https://doi.org/ $\underline{10.2436 / 15.8040 .01 .8}$

RAPER, PETER E. 2000. Introduction to standardization of geographical names. Onoma 35: 187-198. https://doi.org/10.2143/ONO.35.0.574374

SLíz MARIANN 2012. Terminusok keletkezése és változása. Névtani Értesitő 34: 149-156.

SZABÓMihÁLy Gizella 2007. Magyar neve? Szlovákiai magyar helységnevek standardizációs problémái. Névtani Értesitö 29: 189-200.

SZABÓMIHÁLY GiZELLA 2009. A határon túli magyar helynevek standardizációs kérdései. Korunk 3/5: 95-99. 
SZABÓMIHÁLy GiZELla 2013. A szlovákiai magyar helységnevek standardizálásakor alkalmazott elvek. In: BAUKO JÁNOS - BENYOVSZKY KRISZTIÁN szerk., A tulajdonnevek a forditás és a kétnyelvüség kontextusában. Konstantin Filozófus Egyetem Közép-európai Tanulmányok Kara, Nyitra. 54-67.

BÖLCSKEI ANDREA ORCID: 0000-0003-2628-5297

KRE Károli Gáspár Református Egyetem Magyar Nyelv-, Irodalom- és Kultúratudományi Intézet Budapest 